\title{
1 The Structure and Petrology of the Cnoc nan Cuilean 2 Intrusion, Loch Loyal Syenite Complex, north-west Scotland
}

3

4 H.S.R. Hughes ${ }^{1^{*}}$, K.M. Goodenough ${ }^{2}$, A.S. Walters ${ }^{3}$, M. McCormac ${ }^{2}$, A.G. Gunn ${ }^{3}$, A. Lacinska ${ }^{3}$

$5 \quad{ }^{1}$ Cardiff University, School of Earth and Ocean Sciences, Main Building, Park Place, Cardiff CF10 3AT

$6 \quad{ }^{2}$ British Geological Survey, Murchison House, West Mains Road, Edinburgh, EH9 3LA

$7{ }^{3}$ British Geological Survey, Kingsley Dunham Centre, Keyworth, Nottingham, NG12 5GG

$8 \quad$ * Corresponding author: hughesh6@cardiff.ac.uk

9

10

11

12
Category: Research paper

Short title: Petrology of the Cnoc nan Cuilean Intrusion

Words: 8513 (+ 913 in reference list)

References: 34

Figures: 11

Declaration of Interest: None. No conflicts of interest. 


\section{Abstract}

21 In NW Scotland, several alkaline intrusive complexes of Silurian age intrude the 22 Caledonian orogenic front. The most northerly is the Loch Loyal Syenite Complex, which is 23 divided into three separate intrusions (Ben Loyal, Beinn Stumanadh, and Cnoc nan 24 Cuilean). Mapping of the Cnoc nan Cuilean intrusion shows two main zones: a Mixed 25 Syenite Zone (MZ) and a Massive Leucosyenite Zone (LZ), with a gradational contact. The MZ forms a lopolith, with multiple syenitic lithologies, including early basic melasyenites and later felsic leucosyenites. Leucosyenite melts mixed and mingled with melasyenites, resulting in extreme heterogeneity within the $\mathrm{MZ}$. Continued felsic magmatism resulted in formation of the relatively homogeneous $L Z$, invading western parts of the $M Z$ and now forming the topographically highest terrain. The identification of pegmatites, microgranitic veins and unusual biotite-magnetite veins demonstrates the intrusion's complex petrogenesis. Cross-sections have been used to create a novel 3D GoCad ${ }^{\mathrm{TM}}$ model contributing to our understanding of the intrusion.

The Loch Loyal Syenite Complex is known to have relatively high concentrations of rare earth elements (REE), and thus the area has potential economic and strategic value. At Cnoc nan Cuilean, abundant REE-bearing allanite is present within melasyenites of the MZ. Extensive hydrothermal alteration of melasyenites here formed steeply-dipping biotitemagnetite veins, most enriched in allanite and other REE-bearing accessories. This study has thus identified the area of greatest importance for further study of REE enrichment processes in the Cnoc nan Cuilean intrusion. 


\section{1. Introduction}

44 During the Ordovician to Silurian closure of the lapetus Ocean, continental basement and 45 overlying sediments were deformed and metamorphosed during oblique collision of the 46 Laurentia, Baltica, and Eastern Avalonia continental blocks (Soper et al., 1992; Torsvik et al., 47 1996; McKerrow et al., 2000; Dewey \& Strachan, 2003). The resulting Caledonian orogenic 48 belt extends from Scandinavia and East Greenland, through the British Isles and beyond to 49 the Appalachians of North America. Scotland and Ireland (within Laurentia) underwent an 50 early orogenic phase, the Grampian arc-continent collision, with later Silurian Baltica51 Laurentia-Avalonia collision known as the Scandian event (c.435-425 Ma) (Coward, 1990).

52 Caledonian deformation within the NW Highlands was due to this Scandian event. In the 53 Northern Highlands of Scotland, the Caledonian belt is sharply delineated by the Moine 54 Thrust Zone (extending from Loch Eriboll to the Sound of Iona). To the east of this feature 55 the Caledonides comprise Neoproterozoic metasedimentary rocks of the Moine Supergroup 56 (including the Loch Eil, East Moine, and Morar Groups) with some inliers of basement 57 gneiss. To the west, Archaean gneisses of the Lewisian Gneiss Complex, overlain by 58 unmetamorphosed Neoproterozoic and Cambro-Ordovician strata, form a stable foreland 59 block (Johnstone and Mykura, 1989). During the Scandian event, numerous magmatic intrusions were emplaced along the Moine

61 Thrust Zone. These are predominantly alkaline in composition, and range from mafic and 62 ultramafic early phases, to diorites and high Ba-Sr granites and syenites (Thompson \& 63 Fowler, 1986; Tarney \& Jones, 1994; Fowler \& Henney, 1996; Fowler et al., 2008). The most 64 northerly, and youngest, of these intrusions is the late-tectonic Loch Loyal Syenite Complex 65 (Parsons, 1999) - Figure 1. In this paper we present detailed mapping, petrological study 
66 and three-dimensional modelling of the Cnoc nan Cuilean intrusion, the smallest body

67 within the Loch Loyal Syenite Complex, which has been little studied since the work of King 68 (1942). The Cnoc nan Cuilean intrusion is of particular interest at the present time for its 69 notably high rare earth element (REE) contents (Shaw \& Gunn, 1993) and our work 70 investigates how these elements are concentrated within different zones of the intrusion. A

71 new approach for 3D modelling of an igneous intrusion has aided interpretations of its 72 structure, petrogenesis, and REE metallogenesis.

73 (Insert Figure 1)

\section{$74 \quad$ 2. Regional setting}

75 The NW Highlands alkaline plutons are part of a wider suite of high Ba-Sr plutons that occur 76 across the Northern Highlands (Tarney \& Jones, 1994). Petrographically these igneous 77 complexes can be divided into a western zone (syenite-dominated complexes e.g. Glen 78 Dessarry, Loch Loyal, Loch Borralan, and Loch Ailsh) and an eastern zone (e.g. the granite79 dominated suites of Strontian, Rogart, Helmsdale, Cluanie, and Strath Halladale) (Fowler et 80 al., 2008). Of the alkaline magmas, the Loch Loyal Syenite Complex is dominated by quartz 81 syenites, whereas the Loch Ailsh and Loch Borralan plutons show a wider range of 82 compositions, including undersaturated syenites. It is thus likely that more than one 83 magmatic source is represented by these plutons (Parsons, 1972).

84 Recent work on the high Ba-Sr granites and syenites of the NW Highlands has led to the 85 recognition of the Caledonian Parental Magma Array (Fowler et al., 2008). This 86 incorporated a range of magma sources formed by metasomatism of the mantle wedge by 87 various fluids, including those from subducted pelagic carbonates as well as the down-going 
88 slab. Differentiation of magmatic products from the Caledonian Parental Magma Array via

89 fractional crystallisation and concurrent small magma batch assimilation ultimately led to

90 the extensive array of intrusion compositions observed throughout this region. Minor

91 country rock contamination is thought to have occurred throughout this process, affecting

92 the geochemistry of individual intrusions (Fowler, 1988; Fowler, 1992; Fowler et al., 2008).

93 The Loch Loyal Syenite Complex is part of the NW Highlands alkaline plutonic suite, 94 comprising volumetrically small yet highly variable alkaline intrusions of Caledonian age that 95 occur along, and on both sides of, the Moine Thrust Zone. This suite also includes intrusions 96 at Loch Borralan and Loch Ailsh in Assynt (Johnstone \& Mykura, 1989; Parsons, 1999; 97 Atherton \& Ghani, 2002; Fowler et al., 2008; Goodenough et al., 2011). These magmatic 98 events were related to the subduction of lapetus oceanic crust below Laurentia, resulting in 99 the production of ultramafic, mafic, granitic, and syenitic magmas (Thompson \& Fowler, 100 1986; Fowler et al., 2001; Atherton \& Ghani, 2002; Fowler et al., 2008). Thus there is an 101 association between strongly alkaline magmas and a zone of active crustal shortening, 102 rather than extension, in the NW Highlands (Goodenough et al., 2004). This magmatism 103 occurred during and immediately after the Scandian collisional event at 435-425 Ma 104 (Goodenough et al., 2011). The ages of the alkaline intrusions have been used to constrain the timing of regional deformation and development of the Moine Thrust Zone (Halliday et al., 1987; Goodenough 107 et al., 2011). An early magmatic pulse in the Assynt area was emplaced syn-tectonically at $108430.7 \pm 0.5 \mathrm{Ma}$, and was followed by the post-tectonic late suite of the Loch Borralan Pluton 109 at $429.2 \pm 0.5 \mathrm{Ma}$ (Goodenough et al., 2011). Zircons from the Cnoc nan Cuilean syenites 110 have been dated at $426 \pm 9 \mathrm{Ma}$ (Halliday et al., 1987) assumed to be a representative age for 
111 all Loch Loyal Syenite Complex intrusions. More recent attempts at ${ }^{206} \mathrm{~Pb} /{ }^{238} \mathrm{U}$ zircon dating

112 of Cnoc nan Cuilean have suggested an approximate age of 425 Ma. However, the majority 113 of zircons indicate the presence of inherited age components from 1000-2500 Ma 114 (Goodenough et al., 2011). The age of the Loch Loyal Syenite Complex is thus within error of 115 the only other post-tectonic alkaline intrusion in the NW Highlands (the late suite of the 116 Loch Borralan Pluton).

117 The Loch Loyal Syenite Complex is situated in the Tongue district of NW Scotland 118 (Holdsworth et al., 2001) to the east of the Moine Thrust Zone (Fig. 1). The country rocks in 119 this area are chiefly metasedimentary rocks of the Neoproterozoic Moine Supergroup, with 120 some inliers of amphibolite-facies basement gneiss that show similarities to the Lewisian 121 Gneiss Complex of the Caledonian foreland and are termed 'Lewisianoid' (Tanner, 1970; 122 Moorhouse \& Moorhouse, 1977). The Moine rocks of this area belong entirely to the basal 123 Morar Group of the Moine Supergroup, and comprise greenschist to amphibolite facies 124 psammites and pelites. During the Scandian orogenic event these rocks were 125 metamorphosed, folded, and thrust WNW over the Caledonian Foreland along the Moine 126 Thrust.

127 The Loch Loyal Syenite Complex consists of three syenitic masses (Fig. 2) - the Ben Loyal, 128 Cnoc nan Cuilean, and Beinn Stumanadh intrusions (Read, 1931; King, 1942; Robertson \& 129 Parsons, 1974; Johnstone \& Mykura, 1989). It represents the largest area of alkaline rocks in 130 the UK (Parsons, 1999). The Loch Loyal Syenite Complex lies within late Caledonian large 131 cross-folds (Fig. 2) resulting in NW-SE trending country rock foliation, oblique to the 132 region's NNE-SSW orogenic strike (McErlean et al., 1992; Holdsworth et al., 1999). This zone 133 of folding is underlain by the ESE-dipping Ben Blandy shear zone. There is little evidence of 
134 country rock deformation as a direct result of the syenite intrusion. However, limited top-to-

135 the-southeast extension may have occurred on the NW margin of the Ben Loyal intrusion.

136 This indicates that the overall geometry of the Loch Loyal Syenite Complex intrusions has

137 been controlled primarily by the pre-existing country rock structures into which they were

138 intruded (Holdsworth et al., 1999). Throughout the region Caledonian compressional

139 features are post-dated by a series of low-angle faults, probably the result of late-orogenic

140 extension of the Caledonian nappe pile (Holdsworth et al., 2001).

141 The largest intrusion within the complex, Ben Loyal, is separated from the Beinn Stumanadh 142 and Cnoc nan Cuilean intrusions by the Loch Loyal Fault, a major NE-SW trending dextral 143 oblique fault (Holdsworth et al., 2001). It has been suggested that the Ben Loyal intrusion 144 may represent a deeper erosion level, and Beinn Stumanadh and Cnoc nan Cuilean the 145 upper sheeted levels (Holdsworth et al., 1999). However, the Cnoc nan Cuilean intrusion (c.3 $146 \mathrm{~km}^{2}$ ) is significantly chemically different to the Ben Loyal syenites (Parsons, 1999). This 147 contrast is further accentuated by the heterogeneous nature of Cnoc nan Cuilean rocks 148 (King, 1942; Gallon, 1974). The shape of the intrusion has been debated in the past, with 149 suggestions of a rounded outline (King, 1942), a squat ellipsoid (Gallon, 1974) or a series of 150 NW-trending dykes (Holdsworth et al., 2001).

151 Prior to this investigation, little detailed work had been carried out across the Cnoc nan 152 Cuilean intrusion, with early study identifying essentially two broad zones. A relatively 153 homogeneous coarse-grained massive pink syenite in the centre of the intrusion was 154 separated from a structurally complex, heterogeneous 'variable syenite zone' forming the 155 lower marginal slopes of the intrusion (King, 1942). Mafic material within the mixed syenite 156 zone was originally considered to be country rock-derived (King, 1942). All syenites of this 
157 intrusion have lower normative quartz contents, higher orthoclase, and are significantly

158 richer in clinopyroxene and amphibole (Parsons, 1999) than Ben Loyal lithologies. A 159 significant radiometric anomaly was also discovered over the eastern flank of the intrusion 160 due to high concentrations of thorite (Gallagher et al., 1971). This paper presents new data 161 arising from mapping and petrographical study of the Cnoc nan Cuilean intrusion.

\section{2 (Insert Figure 2)}

\section{3. Field relationships at Cnoc nan Cuilean}

164 A new geological map for the Cnoc nan Cuilean intrusion is presented in Figure 3. On the 165 basis of new field data, the syenites of the Cnoc nan Cuilean intrusion are subdivided into 166 two main zones: a 'Mixed Syenite Zone' (MZ) and a 'Massive Leucosyenite Zone' (LZ) (Fig. 3).

167 Discrete episodes of later veining have also been identified. The LZ is defined as an area of 168 massive leucosyenite with less than $10 \%$ of the mafic melasyenite lithology. By contrast, the $169 \mathrm{MZ}$ contains leucosyenite with abundant enclaves of melasyenite, country rock xenoliths 170 (with varying degrees of alteration and assimilation), and other mafic material. The 171 boundary between these zones is gradational (over approximately 50-100 m).

\section{2 (Insert Figure 3)}

\section{3.a. The Mixed Syenite Zone (MZ)}

174 The MZ, which occurs on the lower eastern and south-eastern slopes of Cnoc nan Cuilean

175 (Fig. 3), is a complicated zone that includes both melasyenitic and leucosyenitic lithologies, 176 as well as xenoliths of country rock. This zone is broadly similar to the 'Variable Marginal 177 Syenite' zone of King (1942). Leucosyenites are generally equigranular, medium- to coarse178 grained, and pinkish-white in colour. They comprise plagioclase, K-feldspar and minor 
179 quartz, and black-greenish-brown pyroxene and amphibole, locally with coarse euhedral

180 titanite (with red-brown staining surrounding crystals). In contrast, the darker-coloured 181 melasyenites have higher modal proportions of pyroxene and amphibole (30-65\% mafic 182 minerals), are equigranular (crystal sizes normally ranging up to $1 \mathrm{~mm}$ ) and are generally 183 finer-grained than leucosyenites.

184 The two main lithologies show complex interrelationships, with examples of mingling (the 185 physical coexistence of the two liquids), veining, and a more gradational relationship 186 between the mela- and leucosyenites more indicative of magma mixing. Parts of the $\mathrm{MZ}$ 187 comprise veins of pink leucosyenite and microgranite cutting through massive melasyenite 188 and enclosing polygonal melasyenite enclaves, in some places resembling a stockwork. The $\mathrm{MZ}$ melasyenite can appear as centimetre to metre-scale enclaves, or as more massive bodies cut by a few veins of leucosyenite. Leucosyenite vein contacts here are generally sharp (often with millimetre-scale clinopyroxene selvages) but some gradational contacts 192 (grading over 1-20mm) are encountered, often with wisps of leucosyenite fingering into melasyenites, implying partial assimilation or mixing. Microgranite vein contacts with melaand leucosyenites are always sharp and well defined. Microgranite is distinguished from leucosyenites by its lack of any mafic mineral phases, instead consisting of medium to coarse grained quartz and feldspars only. In some areas, enclaves of melasyenite have 197 lobate contacts against the leucosyenites (Fig. 4a) that indicate extensive magma mingling. Elsewhere, more gradational contacts are seen, indicating mixing resulting in chemical interaction of the syenite magmas (Fig. 4b). Some larger bodies of melasyenite (up to c. 10 200 m wide) have little or no leucosyenite veining. Thus, within the $M Z$ as a whole, there is 201 complete textural variation from angular, blocky melasyenite enclaves that were solid 
202 before intrusion of the leucosyenites, through well-defined rounded melasyenite enclaves

203 with lobate contacts indicating physical mingling of two magmas, to blurred, gradational and 204 indistinct zones of chemical mixing between the two main magmas. It is evident that the 205 melasyenites pre-date the leucosyenites, but that the leucosyenites were intruded whilst 206 the melasyenite magmas were only partly crystallised. The field evidence for two co-existing 207 magmas indicates that the majority of the mafic material in the MZ was not derived from 208 the country rock, as originally suggested by King (1942). Similar features occur in the Loch 209 Ailsh pluton further south, where syenites cross-cut and enclose xenoliths of pyroxenite and 210 melasyenite (Parsons, 1968; Parsons, 1999). Xenoliths of country rock do also occur 211 throughout the $\mathrm{MZ}$, and typically retain their original foliation.

\section{2 (Insert Figure 4)}

\section{3.b. The Massive Leucosyenite Zone (LZ)}

214 The LZ occurs towards the western edge of the intrusion and as the topographically higher 215 outcrops on Meall Eudainn and Creag nan Cat (Fig. 3). This zone comprises massive, coarse216 grained, pink, equigranular, pyroxene and hornblende-bearing leucosyenite. The LZ consists 217 mainly of the same type of leucosyenite as seen in the $M Z$, but here it accounts for more 218 than $90 \%$ of igneous lithologies present. Both here and in the $M Z$, finer-grained light219 coloured leucosyenite veins are observed cross-cutting the main leucosyenite (Fig. 4c). 220 Country rock xenoliths are also observed within this zone, although less commonly than in 221 the MZ. The LZ grades into the MZ over 50-100 metres, with gradually increasing amounts of 222 the melasyenite component as enclaves and larger bodies.

\section{3.c. Pegmatites and volatile-rich veining lithologies}


224 Syenitic pegmatites are commonly encountered in both the $M Z$ and $L Z$, although pegmatites

225 only occur within leucosyenite of these zones (Fig. 4d) and not within melasyenite.

226 Pegmatite can occur as discrete pockets or veins generally $<20 \mathrm{~cm}$ wide and typically with

227 coarse hornblende- or clinopyroxene-rich selvages. The restriction of pegmatite to the

228 leucosyenite lithology suggests that a volatile-rich liquid stemmed from this later felsic

229 magma. Leucosyenite of the LZ contains variable patches of pegmatite, and in turn

230 pegmatite veins and lenses are cross-cut by later leucosyenite and microgranite veins.

231 Pyroxene- and allanite-rich stringers or veinlets are observed throughout the intrusion.

232 Veinlets are discontinuous, up to $5 \mathrm{~mm}$ wide, and cross-cut leucosyenites, melasyenites,

233 xenoliths, and biotite-rich inclusions. Pyroxene/allanite-rich stringers have also been

234 observed being cross-cut by microgranite veins in the Allt Liath stream section of the MZ

235 (Fig. 3). Therefore stringers are likely to have formed from a similar or the same volatile-rich

236 fraction as the pegmatites. In addition pegmatitic veins on the southern slopes of Meall

237 Eudainn contain clots of rhombic pyroxene.

\section{3.d. Microgranite veining}

239 Medium to coarse-grained, pink microgranite veins (containing abundant quartz and no 240 mafic minerals) cross-cut all other magmatic lithologies. This is thought to be the last 241 magmatic event within the intrusion. The veins are generally narrow (up to a few tens of 242 centimetres wide), discordant, and well defined with sharp, planar, intrusive margins. 243 Veining commonly offsets earlier syenites and pegmatite veins, or cross-cuts country rock 244 foliation. This is displayed at [NC 597465] where 10-40 cm wide bifurcating veins trend 245 almost perpendicular to Lewisianoid country rock banding. 


\section{3.e. Biotite-magnetite alteration veins and areas of syenite alteration}

247 Allt Liath, on the eastern side of the Cnoc nan Cuilean intrusion, provides a c. $100 \mathrm{~m}$ east248 west trending section through the MZ. These exposures demonstrate a variety of textures 249 and cross-cutting relationships between all the magmatic lithologies, and provide evidence 250 for alteration of syenites by late fluids. Of particular interest are three highly friable, 251 approximately north-south trending vein systems composed primarily of vuggy or rounded 252 clots of magnetite and flaky biotite books (Fig. 4e). The locations and orientations of these 253 veins are indicated in Fig. 5.

254 These biotite-magnetite veins are up to $40 \mathrm{~cm}$ wide, steeply-dipping, sharply bounded, and 255 black in colour. They are characterised by high total radioactivity and locally high magnetic 256 susceptibility. The biotite-magnetite veins cross-cut all other igneous vein types and 257 syenites, with the exception of some pink microgranite veinlets (usually on the millimetre 258 scale but sometimes up to $10 \mathrm{~cm}$ wide) that anastomose within and across these alteration 259 zones. The biotite-magnetite vein infill observed in situ comprises a friable biotite and 260 magnetite 'matrix' with some more coherent blocks (up to fist-sized) of highly recrystallised, 261 but still recognisable, melasyenite. Thus the veins themselves are not deemed to be of 262 primary igneous origin; they appear to have been the result of intense syenitic alteration, 263 with the vein boundaries delineating the main pathway of late fluid.

264 Although biotite-magnetite vein contacts are clearly delineated visually by their black 265 colour, polygonal blocks of biotite-rich altered syenite up to tens of centimetres in size are 266 also common outside the biotite-magnetite vein margins within the immediately 267 surrounding leucosyenites of the Allt Liath stream section. These 'biotite-rich inclusions' are 268 characterised by coarse biotite crystals overprinting primary magmatic phases. Their field 
269 relations indicate that these too are highly altered melasyenite blocks but appear distinct

270 from the main biotite-magnetite veins due to the possible splaying of these veins in three

271 dimensions. The MZ 'protolith' is very variable and it is possible that the leucosyenites of the

$272 \mathrm{MZ}$ were less dramatically altered due to their lower mafic mineral content, instead only

273 suffering feldspar seritisation and/or kaolinisation.

274 The biotite-magnetite veins formed late in the intrusion's history after the main syenites

275 had fully crystallised, and are the result of pervasive alteration by late-magmatic or

276 hydrothermal fluids. The late microgranite veins were unaffected by this fluid alteration,

277 but may have themselves been the source of the metasomatising fluids.

\section{8 (Insert Figure 5)}

\section{3.f. Country rocks and xenoliths}

280 Country rocks to the Cnoc nan Cuilean intrusion include both Moine and Lewisianoid 281 lithologies. Moine psammites are medium-grained, well-foliated, quartz-rich with varying 282 amounts of biotite. In contrast the Lewisianoid gneiss consists of banded hornblendic 283 tonalite gneiss with some hornblende-rich mafic bands (or 'hornblendites').

284 Country rock xenoliths are common throughout the $M Z$, most particularly at marginal zones 285 [NC 614465] with both Moine and Lewisianoid examples at varying scales. In outcrop some 286 of these xenoliths clearly resemble the surrounding country rock with little or no evidence 287 of recrystallisation and alteration, often with leucosyenite or microgranite veining and relict 288 banding or folding. Some have sharp contacts, whereas in others the contacts are 289 gradational, indicating partial assimilation of the xenoliths by the surrounding magma. 290 However, some xenoliths are almost completely recrystallised, retaining their foliation but 
291 with their mineralogy dominated by biotite (Fig. 4f). These are usually angular, with well-

292 defined and sharp contacts with the host syenite, however these xenoliths have been 293 metasomatised by potassic fluids, resulting in alteration to biotite.

294 In outcrop, Lewisianoid and Moine xenoliths typically occur either as discrete polygonal 295 blocks (up to a few tens of centimetres wide), or as metre-scale blocks fractured to form 296 mosaics of angular inclusions infilled by leucosyenite veining. Lozenge-shaped xenoliths with 297 narrow cross-cutting leucocratic veinlets (1-2 $\mathrm{mm}$ thick) are also observed in conjunction 298 with tightly crenulated xenoliths composed chiefly of coarse biotite and hornblende [NC 299 593463]. These probably originated from mafic bands within the Lewisianoid rocks. Source 300 Lewisianoid hornblendites do not contain biotite, but extensive alteration of xenoliths by 301 potassic fluids within the magma body could have led to this significant biotite overprinting. 302 Thus in combination with other clearly banded Lewisianoid xenoliths, evidence exists for a 303 continuum of xenolithic material varying between almost unaltered non-assimilated blocks 304 to completely metasomatised and replaced inclusions. Moine xenoliths are also observed, 305 displaying similar attributes to the Lewisianoid examples as regards their contacts, size, 306 veining, and alteration.

\section{3.g. Syenite, microgranite and country rock relationships at the intrusion margins}

308 The Moine and Lewisianoid country rocks are folded into an open, upright NW-plunging 309 synform in the immediate vicinity of the intrusion, within a series of major Caledonian cross310 folds (Holdsworth et al., 1999; Holdsworth et al., 2001).

311 Due to poor exposure, particularly at the margins of the Cnoc nan Cuilean intrusion, the 312 outline shape and contact orientations for the intrusion have been deduced from a few key 
313 localities (as outlined below) and inferred from significant changes in topography around

314 the intrusion margins. Although when taken individually very few of these localities may 315 appreciably inform us of the overall shape of the intrusion, cumulatively these have proven 316 most instructive during the interpretation of field data and the construction of cross317 sections. Such localities tend to occur at similar topographic heights around the intrusion, in 318 concentrated zones of basal country rock xenoliths.

319 The NW margin of the intrusion shows a series of massive leucosyenite sheets intruding the 320 Lewisianoid gneisses parallel to their gneissose banding (Fig. 5 - map 1). Key localities 321 demonstrating this concordant relationship (where syenite veins intrude country rocks 322 parallel to their banding and foliation) occur at [NC 593464], [NC 594464], and [NC 595465]. 323 At [NC 593464] highly crenulated biotite-rich Lewisianoid xenoliths can also be observed just 324 a few centimetres away from the leucosyenite/Lewisianoid contact. Rare examples of 325 discordant minor microgranite veins are also observed ([NC 595464] and [NC 598466]), 326 suggesting that this youngest magmatic episode did not necessarily conform to the overall 327 country rock structure to which the main intrusion is constrained.

328 The marginal zone of the intrusion around the stream of Allt Torr an Tairbh (NE margin - Fig.

329 5, Map 2) has a series of small exposures of Lewisianoid gneisses and Moine country rocks, 330 cut by microgranite veins (such as those seen between [NC 609470] and [NC 609471]) and 331 leucosyenite veins, ranging from centimetre-scale up to $5 \mathrm{~m}$ thick, and extending northwards 332 from the lower MZ. Two larger sheets of mixed mela- and leucosyenites are seen from [NC 333610471 ] to [NC 612472] inferred to be approximately 30 and 150m wide respectively 334 (although the syenite sheet/country rock contacts are not always visible) and interpreted as 335 northwards extensions of the lower MZ. Contacts between the Lewisianoid/Moine country 
336 rocks and intrusive sheets are sharp, with little or no evidence of country rock melting and

337 no xenoliths observed. Grain size within these sheets is generally finer $(<1 \mathrm{~mm})$ than the 338 main intrusion. This stream section provides a succession of contacts between intrusive 339 units and country rock, demonstrating that in this marginal zone, syenite sheets and 340 microgranite veins have been intruded as a series of concordant bodies (from centimetre to 341 metre-scale) parallel to Lewisianoid banding and Moine foliation (Fig. 5 - map 2).

342 No exposure of the intrusion margin exists in the area of Bealach na Beiste (SW intrusion 343 margin - Fig. 5 map 3) or along the lower ground on the south side of Meall Eudainn. 344 Therefore the contact marked on Figures 3 and 5 is inferred from a change in slope 345 approximately 500m SW of Lochan nan Cuilean, along with a single locality [NC 605452] 346 consisting of Moine country rock in contact with leucosyenite and cross-cut by numerous 347 narrow leucosyenite and microgranite veins $(3-20 \mathrm{~cm}$ wide) discordant to Moine foliation.

348 On the eastern margin of the intrusion the change in hillside gradient below the crags west 349 and northwest of the Loch Loyal Lodge (Fig. 3) has been used to infer the location of the 350 intrusion/country rock contact. In addition craggy exposures such as those at [NC 615465] 351 show abundant tightly folded and/or foliated Lewisianoid xenoliths (up to $70 \mathrm{~cm}$ long) 352 hosted and veined by leucosyenites. Numerous smaller-scale country rock xenoliths are 353 visible throughout this marginal section of the intrusion, associated with leucosyenite, 354 melasyenite, and pegmatites. 


\section{4. 3D Modelling of the Pluton Geometry}

358 The Cnoc nan Cuilean intrusion is moderately well-exposed, but in many areas the contacts 359 are obscured by superficial deposits, and for this reason there has been debate about the 360 three-dimensional shape of the intrusion (e.g. Holdsworth et al., 1999). In order to 361 understand the extent of the $\mathrm{MZ}$ - and thus the potential scale of the REE-enriched area 362 we have created a Paradigm GOCAD ${ }^{\mathrm{TM}} 3 \mathrm{D}$ model of the Cnoc nan Cuilean intrusion which 363 aids visualisation of the internal and external intrusive relationships. This is one of the first 364 instances that a 3D model has been used to help communicate a research study of a 365 complex igneous pluton in a scientific journal.

366 The model was built using GOCAD $^{\mathrm{TM}}$ software (Paradigm GOCAD ${ }^{\mathrm{TM}} 2009.3$ Patch 3) and 367 represents a rock volume approximately $9 \mathrm{~km}^{2}$ in area and extending to approximately 200 368 metres below the topographic surface. The primary dataset consisted of a 3 by 4 rectilinear 369 grid of hand-drawn vertical structural cross-sections digitally captured in ESRI ${ }^{\circledR}$ ArcGIS $^{\text {TM }}$ (Fig.

370 6). Creating the model (Fig. 7) required several iterations, as the cross-sections that were 371 initially drawn on the basis of field relationships did not produce a reasonable 3D shape for 372 the intrusion. The cross-sections, and our understanding of the 3D size and shape of the 373 intrusion, thus evolved significantly during creation of the model, although always being tied 374 back to the primary field evidence at surface level.

\section{4.a. Summary of field evidence used in cross-section and model construction}

376 The overall surface outline of the LZ was based on the prevalence of massive leucosyenite 377 and absence of melasyenite on higher exposures of Meall Eudainn and Creag nan Cat. Based 378 on exposures at [NC 598457] and satellite imagery, two faults have been interpreted within 
379 the intrusion (mapped as Faults 1 and 2). An elongate zone of massive leucosyenite, 380 exposed around Meall nan Eudainn and Creag nan Cat, extends along Fault 1 and is inferred 381 to have been the result of leucosyenite magma being fed along this fault. Thus cross382 sections 5, 6, and 7 (Fig. 6) document this leucosyenite body narrowing eastwards from 383 Cnoc nan Cuilean along Fault 1 and Creag nan Cat. In turn, a similar system along Fault 2 384 may go some way to explaining why a small zone of $L Z$ can be observed to the north of the 385 intrusion at [NC 606467].

386 The steeper LZ sheets on the $\mathrm{W}$ of the intrusion (particularly around Cnoc nan Cuilean itself) 387 are seen in the field as previously described in Section 3.g. However, the detailed deeper 388 relationship between the $M Z$ and $L Z$, as shown on the eastern side of cross-sections 3 and 4 389 (Fig. 6), is interpretive and based on the field evidence of surrounding country rock structure 390 (a northward plunging synform) which indicates that the $M Z$ and $L Z$ are generally 391 constrained to a lopolithic shape concordant with this structure. Therefore the later 392 introduction of massive leucosyenites to the earlier melasyenites resulted in the LZ fingering 393 into the MZ. These veining relationships internal to the intrusion are likely to be more 394 complicated than can be shown by this model, and those shown here are intended as 395 representative, to demonstrate the processes forming the intrusion.

396 (Insert Figure 6)

397 4.b. The modelling process

398 To create the model, the geo-referenced cross-section shapefiles were imported directly to $399 \mathrm{GOCAD}^{\mathrm{TM}}$ along with the crop limit lines of the two syenite bodies (the $\mathrm{MZ}$ and $\mathrm{LZ}$ ) and a set 400 of $10 \mathrm{~m}$ topographic contours. Shapefiles were converted within $\mathrm{GOCAD}^{\mathrm{TM}}$ to depth (Z) 
401 attributed point sets, thereby providing a 'data cage' to constrain the model surface 402 geometry of the two syenite bodies. However, the intrusive surfaces proved problematic to 403 model directly from the cross-section data, as they were too widely spaced to define the 404 convoluted surface structure in 3 dimensions. To work around this, a stack of structure405 depth contours were constructed by linking matching elevation points on the cross-section 406 lines.

407 Approximations to the outer subsurface limits of the two syenite bodies were then created 408 by manual GOCAD ${ }^{\mathrm{TM}}$ surface construction functions, building the surface in upward steps 409 between adjacent depth contours. The resulting, approximately cylindrical, surface objects 410 were then fitted to the original cross-section line data using the GOCAD ${ }^{T M}$ Discrete 411 Smoothing Interpolation algorithm (Mallet, 1997; Mallet, 2002). A smoothing and manual 412 surface edit operation was carried out to clean irregular artefacts and self-intersections in 413 the surface mesh and the modelled shape and extent of the major intrusive apophyses were 414 refined. It should be noted that many of the minor sheets, veins, and irregularities portrayed 415 on the cross-sections were at the limit of the practical resolution scale of the model and are 416 represented in simplified form. The top surface of the model intrusion, which corresponds 417 to the ground surface outcrop, was created separately from the Digital Terrain Model and 418 merged with the subsurface model surfaces.

419 (Insert Figure 7)

$420 \quad$ 4.c. Model results

421 Figure 7 displays a variety of snapshot views from the final 3D model of the Cnoc nan 422 Cuilean intrusion. It demonstrates the saucer-shaped lopolith of the MZ (Fig. 7c) broadly 
423 following the northward-plunging synformal structure of the Lewisianoid and Moine country

424 rocks (although these have not been included in the model for clarity). Through this initial 425 shallow intrusion, the LZ was intruded from a feeder zone located at the south-western or 426 western edge of the intrusion, with leucosyenitic magma becoming channelled along faults 427 within the intrusion (particularly Fault 1 trending NE-SW, Fig. 6). This resulted in the 428 elongated shape of the LZ in a NE direction (Fig. 7a). In addition, leucosyenites formed a 429 series of sheets approximately concordant to host Lewisianoid or Moine fabrics, as 430 displayed on the northern and NW sides of the intrusion, and best displayed by the 431 underside snapshot view of Figure 7b.

432 This 3D model is undoubtedly an interpretation, based on the observed field relationships 433 and our understanding of the processes that formed the Cnoc nan Cuilean intrusion. It is, of 434 course, constrained by only the available data from limited surface exposures. However, the 435 iterative process of building a 3D model has helped our understanding of the intrusion 436 shape to develop. We are confident that the model presented here provides a best estimate 437 of the 3D shape of the intrusion on the basis of the existing data, and it can be used as a 438 template for further investigation of Cnoc nan Cuilean.

\section{5. Petrology of intrusion lithologies}

\section{$441 \quad$ 5.a. Melasyenite}

442 Melasyenites of the MZ comprise c. 45-60\% feldspar and more than $30 \%$ mafic minerals. 443 Although the amount of mafic minerals is very variable, there is no systematic trend or 444 zonation across the intrusion. Most melasyenites are medium- to coarse-grained, but some 
445 finer grained examples are encountered on the south side of Meall Eudainn and the east 446 side of Creag nan Cat. They are not porphyritic, but locally feldspars can be notably coarser 447 than mafic phases. Some are foliated, due to alignment of elongate pyroxenes.

448 Both plagioclase and K-feldspar are present in the melasyenite, but plagioclase is generally 449 less than $15 \%$ of the rock. K-feldspars are typically subhedral and interstitial to mafic 450 minerals and generally show perthitic exsolution lamellae. Quartz is present, but at less than $4515 \%$, and often has undulose extinction.

452 Mafic minerals include clinopyroxene (aegirine-augite to diopside), alkali amphibole and 453 titanite. Biotite does not occur as a primary magmatic phase, but patchy alteration of 454 syenites by late fluids is highlighted by the occurrence of tabular biotite crystals. Minor 455 magnetite flecks are observed, particularly as inclusions within clinopyroxene crystal rims. 456 Pyroxenes occur at much higher concentrations than amphiboles (usually > 3:1). Titanite, 457 commonly exceeding $5 \%$ content, occurs as euhedral rhombs up to $0.5 \mathrm{~mm}$ long, and is 458 frequently found clustered with clinopyroxene and apatite (Fig 9a). Generally, mafic 459 minerals often cluster together. Examples of both clinopyroxene with euhedral prismatic 460 titanite inclusions, and large subhedral titanites with rounded pyroxene inclusions are 461 observed. Pyroxene clusters may be rounded (sometimes in an orbicular texture) or as 462 stringers through the sample (Fig. 8a). One orbicular melasyenite (south Meall Eudainn) 463 shows individual rounded pyroxene crystals delineating the outer edge of the orbicules (Fig. 464 8b). The orbicule interiors contain similar shaped pyroxene crystals, titanite, and interstitial 465 K-feldspar. Coarse perthitic K-feldspar (and minor plagioclase) infills between the orbicules. 466 The origins of this texture are uncertain but they may have resulted from the replacement 467 of large primary rounded crystals, or have been formed during movement of crystal mush. 
468 Rounded or granular, anhedral apatite crystals are common in melasyenites, often clustered

469 with pyroxenes or titanite. They often have a rim of allanite, are associated with more 470 blocky crystals of allanite, or have allanite infilling fractures (Fig. 8c). Allanite is also 471 observed as a late-magmatic phase interstitial to pyroxenes, titanite and apatite, or in veins 472 in some samples.

473 (Insert Figure 8)

\section{5.b. Leucosyenite}

475 The leucosyenites of $\mathrm{Cnoc}$ nan Cuilean are white-pink, generally unfoliated medium- to 476 coarse-grained massive syenites with less than $30 \%$ summed total of pyroxene, amphibole, 477 and titanite. Feldspars account for more than $50 \%$ of the leucosyenite, with higher 478 proportions of K-feldspar (perthite) than plagioclase. 5-15\% quartz is generally present. 479 Allanite and apatite occur in markedly lower concentrations, with samples rarely displaying 480 the late-magmatic relationship of rounded apatite crystals rimmed by allanite. Allanite only 481 occurs as a rare fracture infill in some samples (predominantly from the Allt Liath area).

\section{5.c. Microgranite}

483 Microgranite occurs as veins throughout the Cnoc nan Cuilean intrusion, characterised by its 484 lack of mafic and accessory minerals. In rare cases mafic minerals are entrained from host 485 syenites. The microgranites are medium-grained, unfoliated and consist of equigranular 486 plagioclase, K-feldspar, and quartz. Plagioclase is the dominant feldspar (50-60\%) with 487 lesser K-feldspar (c. 20\%). 
488 Some recrystallisation (typically associated with the introduction of biotite, allanite, or 489 clinopyroxene) occurs along the contacts of the microgranite veins with the mela- and 490 leucosyenites, indicating a higher volatile content within these younger granitic melts.

\section{$491 \quad$ 5.d. Pegmatites}

492 Pegmatites contain large $(5-15 \mathrm{~mm})$ euhedral zoned clinopyroxenes (aegirine-augite to 493 diopside), ranging from colourless at the core to green at the rim (in PPL) and typically 494 growing inwards from pegmatite vein margins. These phenocrysts are commonly twinned 495 and have abundant inclusions of magnetite and fine apatite, particularly concentrated 496 towards crystal rims. Additionally, finer subhedral clinopyroxene $(0.25-1 \mathrm{~mm})$ occurs as a 497 selvage, commonly clustered around apatite. Acicular or bladed coarse apatite crystals grow 498 orthogonal to vein margins and also occur as inclusions within clinopyroxene phenocrysts. 499 They frequently have thin rims of allanite and allanite as fracture infill. Fractures through 500 pyroxene phenocrysts are infilled by fine K-feldspar or allanite.

501 Feldspars are predominantly coarse K-feldspar, typically with perthitic exsolution with rare 502 inclusions of magnetite or clinopyroxene $(<0.1 \mathrm{~mm})$. Titanite is common, often clustered 503 amongst the finer marginal clinopyroxene phases, and is generally subhedral to prismatic.

\section{$504 \quad$ 5.e. Allanite veinlets}

505 Allanite is observed as a veining phase within syenite samples (usually restricted to syenites 506 within the Mixed Syenite Zone, particularly near the hydrothermal biotite-magnetite veins 507 of the Allt Liath stream section). Such fracture infills (Fig. 9b) are interpreted as evidence for 508 a period of volatile-rich magmatic-hydrothermal allanite growth, which occurred late in the 509 history of the intrusion and after crystallisation of host syenites, perhaps due to fluids 
510 introduced to the intrusion during pegmatite crystallisation. It is likely that this stage

511 resulted from remobilisation of accessory minerals and allanite of primary magmatic origin

512 within syenites. Brown-orange allanite veinlets vary from $<1 \mathrm{~mm}$ to $4 \mathrm{~mm}$ thick, cross-cut

513 and offset by microgranite veins, indicating that this granitic veining stage occurred after

514 allanite veins. Overall multiple episodes of late fluid-related veinlets of allanite have formed

515 within the Cnoc nan Cuilean intrusion.

516 (Insert Figure 9)

517 6. Biotite-magnetite REE-rich veins and metasomatised melasyenites

518 Material from the biotite-magnetite veins of the Allt Liath stream section in the MZ (as

519 mentioned in 3.e.) is extremely heterogeneous. In outcrop, moderately altered melasyenitic

520 wall rock ('biotite-rich inclusions') is observed within the leucosyenites and microgranite

521 outside of these vein boundaries. Melasyenites included within the biotite-magnetite veins

522 themselves are completely metasomatised and nodules of this material are suspended in a

523 highly friable matrix of coarse biotite and magnetite.

\section{6.a. Biotite-magnetite vein mineralogy}

525 Biotite-magnetite veins are chiefly composed of biotite, magnetite, clinopyroxene, allanite, 526 apatite, baryte, amphibole, and rare perthitic K-feldspar. In addition a large array of 527 accessory minerals are also observed, including an allanite-like mineral (a lighter yellow528 brown colour in thin section forming repetitively zoned rims around true allanite crystal 529 cores - Fig. 10a), strontianite, thorite, and U-Th and U oxides. Various REE- and REE-Sr530 carbonates have also been found as minor veinlets through allanite, the allanite-like 531 mineral, and apatite in this lithology (Fig. 10a). 
532 Multiple stages of mineral growth are observed in biotite-magnetite vein material. Zoned

533 green clinopyroxene is widespread, varying from coarse crystals to fine clustered and highly

534 fractured phases. In some cases, small granular pale green clinopyroxene inclusions occur

535 within coarse tabular biotite. Biotite is widespread with multiple generations. For example,

536 small tabular brown biotite crystals (<0.5 mm long) occur within coarse subhedral dark

537 green biotite. Biotite also occurs in clustered patches or veins, and as discrete tabular

538 crystals replacing other originally melasyenite mafic minerals (predominantly pyroxenes)

539 and is commonly associated with amphibole. Magnetite (comprising up to $20 \%$ of the

540 lithology) occurs in two main forms: as a massive vuggy phase with common inclusions of

541 biotite, apatite, allanite, and baryte (Fig. 10b); and as smaller crystals typically concentrated

542 at well-defined margins in contact with primary syenites. K-feldspar is normally found

543 between clinopyroxene clusters and has typically undergone sericitic alteration, but

544 perthitic exsolution is still locally evident. Allanite and its alteration products are prevalent,

545 locally comprising $25 \%$ of the lithology. This mineral also occurs in several generations

546 ranging from coarse or blocky core crystals, to highly zoned and complex allanite and

547 allanite-like mineral layers on crystal rims and infilling fractures. Apatite occurs as massive

548 rounded clusters of coarse and highly fractured crystals (often with allanite and other rare

549 earth element (REE)-bearing minerals infilling cracks).

550 External to the biotite-magnetite veins, moderately altered melasyenite blocks (usually

551 polygonal) are hosted within leucosyenite or surrounded by microgranite. These still display

552 relict syenite mineralogy and textures, but carbonate and clays have pervasively and

553 completely replaced the feldspar component (Fig. 10c). Tabular biotite occurs throughout

554 (up to c. $50 \%$ biotite) locally becoming coarse-grained in proximity to microgranite veinlets 
555 which cross-cut these altered blocks. Rounded apatite crystals appear unaltered and occur

556 in carbonate alteration patches and amongst biotite. Apatite commonly has allanite at its 557 margins, although some coarser examples of allanite (interstitial to apatite and biotite) are 558 also present. Rare relict amphibole and pyroxene are now poikilitic (Fig. 10c) and display 559 partial overprinting by fine tabular biotite. Unlike material from within the biotite-magnetite 560 veins however, these metasomatised melasyenites do not display such a wide variety of 561 accessory minerals (no baryte, strontianite, thorite, U-Th oxides, or REE carbonates have 562 been observed) and nor do they contain any significant magnetite. In addition, the main 563 minerals within the biotite-magnetite veins tend to be coarsely crystalline, while these 564 partially metasomatised rocks external to the veins are generally finer grained.

565 (Insert Figure 10)

\section{6.b. Melasyenite alteration and veining by late fluids}

567 Overall, the textures seen within and around these veins provide evidence of widespread 568 and variable fluid alteration of the original melasyenites present in this area. Original 569 primary magmatic mafic minerals have been largely replaced by secondary biotite and the 570 growth of allanite and magnetite, while feldspars have either been sericitised, kaolinised, or 571 replaced by carbonates. The high proportion of replacement minerals (biotite \pm magnetite \pm 572 allanite \pm carbonate \pm clays $>80 \%$ ) indicates significant metasomatism of melasyenites. The 573 fluids causing this alteration could have been late-magmatic or hydrothermal in origin. The 574 variation observed between altered melasyenites within, and external to, biotite-magnetite 575 veins is likely the result of lesser fluid-present alteration in syenites external to the main 576 fluid pathway (now inferred by the friable veins themselves), such that the original lithology 577 is still recognisable in some places. This interpretation is further supported by the frequent 
578 occurrence (within 30 m of biotite-magnetite veins) of leucosyenites and hybrid or mixed 579 leucosyenite-melasyenites, whose feldspars have undergone extensive sericitisation and 580 kaolinisation, carbonate replacement, and partial replacement of pyroxenes by magnetite. It 581 may be that further biotite-magnetite veins are present within this area, and that the 582 structural features of this 'alteration zone' are not fully displayed by the limited and 583 unidirectional exposures of the Allt Liath stream section.

\section{7. Discussion}

585 The Cnoc nan Cuilean intrusion is the smallest (c. $3 \mathrm{~km}^{2}$ ) and most heterogeneous body 586 within the Loch Loyal Syenite Complex (Robertson \& Parsons, 1974; Parsons, 1999; 587 Holdsworth et al., 2001), containing multiple igneous lithologies and zones of alteration. We 588 have divided the intrusion into two main zones as described above: the Mixed Syenite Zone 589 (MZ) and the Massive Leucosyenite Zone (LZ). The field mapping, derived cross-sections, and 590 3D modelling (Fig. 7) indicate that the structure of the Cnoc nan Cuilean intrusion was 591 initially that of a saucer-shaped lopolith. The first intrusive episode involved passive and 592 largely concordant emplacement of earlier melasyenitic magmas into a broad plunging 593 synform within Lewisianoid and Moine rocks. This structural interpretation differs from 594 previously proposed models of a simple NW-trending set of steeply-dipping sheets through 595 country rock (Holdsworth et al., 1999). Our models clearly show that the main structure 596 within the intrusion is the gradational contact between the MZ and LZ which extends across 597 the whole pluton, and is not compatible with emplacement as a series of coalescing sheets. 598 Sheeted contacts are evident in some of the northern marginal areas of the intrusion (for 599 the LZ in the NW margin, and MZ and LZ in the NE margin) where sheeting and minor 600 veining of melts occurs and is most typically concordant with the gently-dipping fabric in the 
601 country rock. Xenoliths were incorporated as magma fingered out into the surrounding host

602 rock from a feeder zone, thought to be situated towards the western side of the intrusion, 603 just south of Cnoc nan Cuilean itself. During a second intrusive episode, felsic syenitic 604 magmas were emplaced, intruding into and mixing with the earlier melasyenite lopolith to 605 ultimately form the MZ. Textural evidence suggests that the melasyenites of the MZ were a 606 crystal mush of variable melt fractions, hence producing a variation from lobate blebs of the 607 mingled syenitic magmas, to gradational changes from one syenite lithology to another, 608 suggesting a chemical as well as a physical interaction and assimilation during mixing. This 609 would therefore imply no major break in the magmatic replenishment of the Cnoc nan 610 Cuilean intrusion (between Stages 1 and 2, Fig. 11). During this episode country rock 611 xenoliths within the melasyenites were fractured and veined by leucosyenite, and additional 612 new country rock xenoliths became entrained.

613 Continuing leucosyenite intrusion into higher levels of the lopolith eventually led to the 614 formation of the LZ (Stage 2 - Fig. 11) with magma being fed along two main faults (trending 615 approximately $\mathrm{N}-\mathrm{S}$ and NE-SW) resulting in the observed elongate structure of the LZ 616 forming the high ground of Creag nan Cat. In areas closer to the inferred feeder zone, 617 homogeneous LZ syenites were formed as the intrusion inflated from the centre of the 618 leucosyenite intrusion, such that early mafic material became inundated or fully assimilated, 619 leaving little evidence of the early melasyenites in these western, central, and higher areas 620 of the intrusion. However this was a variable process, and hence the boundary between 621 what is now the $M Z$ and $L Z$ is a gradual one. Evidence of emplacement of two (or more) 622 magma batches distinguishes the Cnoc nan Cuilean intrusion from the other more 623 homogeneous intrusions within the Loch Loyal Syenite Complex (Parsons, 1999) and 
624 suggests a prolonged magmatic history involving multiple episodes of magma 625 replenishment.

626 Overall, the entire intrusion process was likely initially facilitated by late Caledonian gravity627 driven extension of Moine Thrust sheets (Holdsworth et al., 1999). Melt ingress was aided 628 by extensional faulting observed across the pluton, particularly in an E-W direction (Stage 1 629 - Fig. 11). All magmatic units were fed from a deeper evolving and replenishing magma 630 chamber up to the lopolith level. This mechanism has been inferred for the Ben Loyal 631 intrusion, with the foliations observed in its marginal zones thought to have developed 632 during the movement of a nearly solid crystal mush (Robertson \& Parsons, 1974). This 633 supports the hypothesis of mobile partially crystalline melts moving to higher crustal 634 regions.

635 Throughout magma batch replenishment, the variable volatile content led to patchy and 636 variable forms of pegmatite veining, allanite stringers, or a combination of the two occurring 637 as long narrow veins and irregular inclusions within syenites, often cross-cut and offset by 638 later microgranite veins. These microgranite veins post-date all other lithologies within the 639 Cnoc nan Cuilean intrusion and thus represent the last magmatic event.

640 In the waning stages of magmatism, an episode of fluid-present alteration led to the 641 crystallisation of coarse biotite, magnetite, hornblende, and allanite in discrete sub-vertical 642 veins within the MZ. The Allt Liath stream section displays three N-S trending, steeply 643 dipping narrow veins of this type. The fluids responsible for the alteration may be late644 magmatic metasomatic, or may be derived from a hydrothermal system. In some cases, a 645 fine anastomosing network of microgranite veinlets can be observed within these zones. It is 646 therefore suggested that the modifying fluid phase and the invasive microgranite veining 
647 lithology are broadly coeval (Stage 3 - Fig. 11), perhaps with the replenishing batch of 648 magma ultimately introducing a large volume of metasomatic fluids, resulting in fluid-rich 649 alteration. Thus, given the extensive occurrences of microgranitic veins, it is possible that 650 biotite-magnetite veins may be more extensive in the $M Z$ than currently suggested by 651 surface exposure. However due to their friable nature and vulnerability to erosion, these are 652 not exposed on the highly vegetated and peat-covered surfaces of the intrusion.

653 During biotite-magnetite vein formation in the $M Z$, host syenites were variably 654 metasomatically altered. During this process, syenites underwent almost complete 655 replacement of the primary magmatic mineralogy by coarse biotite, magnetite, 656 clinopyroxene, allanite, apatite, and carbonates. These highly altered biotite-magnetite 657 lithologies are most commonly found within the north-south veins, but also occur in discrete 658 patches in the surrounding MZ syenites of Allt Liath, often associated with microgranite. 659 This may indicate the presence of more biotite-magnetite veins in this area, since eroded or 660 forming a more complex 3D arrangement.

661 The apparent scarcity of these biotite-magnetite veins may be due to their weathering 662 propensity and extreme friability, and thus it is likely that these have been preferentially 663 eroded. We consider it likely that a much more extensive network of these veins exists, 664 however these will only be identifiable by geophysical studies due to the lack of exposure. 665 Overall the structural control on this alteration event remains unclear. The biotite666 magnetite vein occurrence at the intrusion margin may have resulted from the potentially 667 greater mobility of fluids in this region with veins trending parallel to the intrusion edge. 668 Alternatively the veins could be infilling a N-S-trending fracture system. 
669 The Loch Loyal Syenite Complex is enriched in the rare earth elements (REE) relative to 670 other intrusions in the UK, even in the more homogeneous syenites of its three constituent 671 intrusions (Plant et al., 1969; Shaw \& Gunn, 1993). It represents an enriched member of the 672 Caledonian Parental Magma Array (Halliday et al., 1987; Fowler et al., 2008). At Cnoc nan 673 Cuilean, REE-bearing minerals (predominantly LREE-rich allanite) are concentrated in the 674 melasyenites of the $\mathrm{MZ}$, and particularly in the altered biotite-magnetite veins. The REE are 675 incompatible, and so REE-bearing minerals might generally be expected to be found in 676 more-evolved magmatic lithologies, such as pegmatites. However, at Cnoc nan Cuilean, the 677 REE are concentrated in accessory minerals (particularly allanite) which are most abundant 678 in the more mafic, less-evolved lithologies (melasyenites) and are then further concentrated 679 through alteration by late-stage fluids of magmatic or hydrothermal origin. The $M Z$ is not 680 well exposed, and may potentially contain more areas of alteration that have similarly high 681 REE contents. It is likely that similar processes operate in other intrusions, and therefore this 682 has important consequences for our understanding of how REE-bearing minerals form, and 683 hence for REE exploration.

684 This work has allowed us to develop a clearer picture of the structure of the Cnoc nan 685 Cuilean intrusion, aiding future exploration for REE mineralisation in this and other similarly 686 poorly exposed intrusive bodies. Key to this success has been the development of a working 687 and interactive 3D model, constructed from field mapping data equivalent to that obtained 688 during early-stage mineral reconnaissance and exploration programmes. The intrusion may 689 further be used to understand the processes by which REE become concentrated in 690 magmatic and post-magmatic settings.

691 (Insert Figure 11) 


\section{8. Conclusions}

693 New mapping presented here contributes to a new interpretation of the structure of the

694 intrusion, demonstrating that an initially lopolith shaped melasyenite magma body was

695 inundated by leucosyenites during its crystallisation. Thus the intrusion can be divided into

696 two zones according to melasyenite content, with a gradational boundary in between them.

697 In addition, pegmatites, allanite- and pyroxene stringers, and microgranite veins are

698 widespread throughout the intrusion. LREE-bearing minerals, predominantly allanite, are

699 concentrated in melasyenites rather than in the more evolved leucosyenites. In turn,

700 allanite has been further concentrated in biotite- and magnetite-rich veins on the eastern

701 side of the intrusion by late fluid alteration. This has significantly enriched REE in these

702 structures.

703 Together with cross-sections, mapping has been used to build an interactive 3D GoCAD ${ }^{\mathrm{TM}}$

704 model of the Cnoc nan Cuilean syenite body. The model has allowed for the testing of

705 structural interpretations and cross-section validity relative to known field observations.

706 This provides a low cost working visualisation process that can be employed at a very early

707 stage in exploration or mineral reconnaissance in complex igneous geology settings

708 suffering from limited exposure. With the novel and innovative use of a 3D intrusion model,

709 a more detailed understanding of the intrusion's shape and thus the areas of potential

710 interest for REE mineralisation can be established. Overall this intrusion contributes to our

711 understanding of processes important to critical metal metallogenesis. 
714 The authors would like to thank colleagues at BGS (Keyworth and Edinburgh) for help and discussion during this

715 research. M. Fowler (University of Portsmouth) and an anonymous reviewer are thanked for their helpful

716 comments towards the manuscript. Thanks are extended to M. Styles, T. Milodowski, J. Rushton and M. Allen

717 (Keyworth). C. Richie, T. Kearsey and R. Terrington are thanked for their part in the production of the 3D model.

718 Lastly, J. Hughes and D. Paterson are thanked for their logistical aid in the field, along with the staff and

719 proprietors of the Tongue Hotel for such a pleasant stay during fieldwork. H.S.R.H. acknowledges the financial

720 support of the Natural Environment Research Council (NERC); the BGS University Funding Initiative (BUFI); and

721 the Schools Competition Act Settlement Trust (SCAST) for sponsorship of this research. 
References:

Atherton, M. P. \& GhanI, A. A. 2002. Slab breakoff: a model for Caledonian, late granite syncollisional magmatism in the orthotectonic (metamorphic) zone of Scotland and Donegal, Ireland. Lithos, 62, 65-85.

CoWARD, M. P. 1990. The Precambrian, Caledonian and Variscan framework to NW Europe. Geological Society, London, Special Publications, 55, 1-34.

DeWEY, J. F. \& StRACHAN, R. A. 2003. Changing Silurian-Devonian relative plate motion in the Caledonides: sinistral transpression to sinistral trantension. Journal of the Geological Society, London, 160, 219-229.

FOWLER, M. B. 1988. Elemental evidence for crustal contamination of mantle-derived Caledonian syenite by metasediment anatexis and magma mixing. Chemical Geology, 69, 1-16.

FOWLER, M. B. 1992. Elemental and O-Sr-Nd isotope geochemistry of the Glen Dessarry syenite, NW Scotland. Journal of the Geological Society, 149, 209-220.

FoWleR, M. B. \& HENNEY, P. J. 1996. Mixed Caledonian appinite magmas: Implications for lamprophyre fractionation and high Ba-Sr granite genesis. Contributions to Mineralogy and Petrology, 126, 199-215.

Fowler, M. B., Henney, P. J., Darbyshire, D. P. F. \& Greenwood, P. B. 2001. Petrogenesis of high Ba-Sr granites: the Rogart pluton, Sutherland. Journal of the Geological Society, London, 158, 521534.

Fowler, M. B., Kocks, H., DarbyshiRe, D. P. F. \& Dreenwood, P. B. 2008. Petrogenesis of high Ba-Sr plutons from the Northern Highlands Terrane of the British Caledonian Province. Lithos, 105, 129-148.

GallagheR, M. J., Michie, U. M., SMITH, R. T. \& HAYNeS, L. 1971. New evidence of uranium and other mineralization in Scotland. Transactions of the Institution of Mining and Metallurgy, 80, 150173.

GALLON, A. C. 1974. Geological and geochemical aspects of the Loch Loyal Alkaline Complex, Sutherland. PhD, University of Leeds.

Goodenough, K. M., Millar, I., Strachan, R. A., Krabbendam, M., et al. 2011. Timing of regional deformation and development of the Moine Thrust Zone in the Scottish Caledonides: constraints from the U-Pb geochronology of alkaline intrusions. Journal of the Geological Society, London, 168, 99-114.

Goodenough, K. M., Young, B. N. \& PARSons, I. 2004. The minor intrusions of Assynt, NW Scotland: early development of magmatism along the Caledonian Front. Mineralogical Magazine, 68, 541-559.

Halliday, A. N., AfTALION, M., PARsons, I., Dickin, A. P., et al. 1987. Syn-orogenic alkaline magmatism and its relationship to the Moine Thrust Zone and the thermal state of the Lithosphere in NW Scotland. Journal of the Geological Society, London, 144, 611-617.

HOLDSWORTH, R. E., MCERLEAN, M. A. \& StRACHAN, R. A. 1999. The influence of country rock structural architecture during pluton emplacement: the Loch Loyal syenites, Scotland. Journal of the Geological Society, London, 156, 163-175.

Holdsworth, R. E., STRACHAN, R. A. \& AlsOP, G. I. 2001. Solid geology of the Tongue District: Memoir for 1:50,000 Geological Sheet 114E (Scotland), British Geological Survey.

JOHNSTONE, G. S. \& MYKURA, W. 1989. Younger Caledonian igneous rocks. In: British Regional Geology: The Northern Highlands of Scotland. pp. 102-117. British Geological Survey. 4th ed.

KING, B. C. 1942. The Cnoc nan Cuilean area of the Ben Loyal Igneous Complex. Quarterly Journal of the Geological Society, 98, 147-185.

MALlet, J. L. 1997. Discrete Modeling for Natural Objects. Mathematical Geology, 29, 199-219.

MALLET, J. L. 2002. Geomodeling, New York, Oxford University Press. 
McErlean, M. A., Holdsworth, R. E. \& Strachan, R. A. 1992. The deformation and emplacement of the Loch Loyal Syenite Complex, Northern Scotland. Joint Annual Meeting of the Mineralogical Society of Canada and the Geological Association of Canada. Acadia University, Wolfvill, Nova Scotia: Geological Association of Canada.

MCKERROW, W. S., MACNIOCAILL, C. \& DeWEY, J. F. 2000. The Caledonian Orogeny redefined. Journal of the Geological Society, London, 157, 1149-1154.

MOorhouse, S. J. \& MOORHOUSE, V. E. 1977. A Lewisian basement sheet within the Moine at Ribigill, north Sutherland. Scottish Journal of Geology, 13, 289-300.

PARSONS, I. 1968. The origin of the basic and ultrabasic rocks of the Loch Ailsh alkaline intrusion, Assynt. Scottish Journal of Geology, 4, 221-234.

PARSONS, I. 1972. Comparative petrology of the leucocratic syenites of the Northwest Highlands of Scotland. Geological Journal, 8, 71-82.

PARSONS, I. 1999. Loch Loyal Syenite Complex. In: Caledonian Igneous Rocks of Great Britain. (eds. Stephenson, D., BEVInS, R. E., Millward, D., HIGHTON, A. J., et al.).

Plant, J. A., Gallagher, M. J. \& SMITH, R. T. 1969. Geochemical survey of the Ben Loyal syenite complex, Sutherland. London: Institute of Geological Sciences, Radiogeology and Rare Minerals Unit.

READ, H. H. 1931. The geology of central Sutherland.

RoberTSON, R. C. R. \& PARSONS, I. 1974. The Loch Loyal Syenites. Scottish Journal of Geology, 10, 129146.

SHAW, M. H. \& GUNN, A. G. 1993. Rare Earth Elements in Alkaline Intrusions North-West Scotland. Mineral Reconnaissance Programme. British Geological Survey.

SOPER, N. J., StRACHAN, R. A., HOldSWORTH, R. E., GAYER, R. A., et al. 1992. Sinistral transpression and the Silurian closure of lapetus. Journal of the Geological Society, London, 149, 871-880.

TANNER, P. W. G. 1970. The Sgurr Beag Slide-a major tectonic break within the Moinian of the Western Highlands of Scotland. Quarterly Journal of the Geological Society, 126, 435-463.

TARNEY, J. \& JONES, C. E. 1994. Trace element geochemistry of orogenic igneous rocks and crustal growth models. Journal of the Geological Society, London, 151, 855-868.

THOMPSON, R. N. \& FOWLER, M. B. 1986. Subduction-related shoshonitic and ultrapotassic magmatism: a study of Siluro-Ordovician syenites from the Scottish Caledonides. Contributions to Mineralogy and Petrology, 94, 507-522.

Torsvik, T. H., SMethurst, M. A., Meert, J. G., VAN DeR Voo, R., et al. 1996. Continental break-up and collision in the Neoproterozoic and Palaeozoic - A tale of Balitca and Laurentia. Earth-Science Reviews, 40, 229-258. 
810 List of figure captions:

811 Figure 1. Simplified regional geological map of NW Scotland, displaying the main faults, 812 thrust, and Caledonian intrusions. Major thrusts include: Moine Thrust (MT), Naver Thrust 813 (NT), Ben Hope Thrust (BHT), and the Sgurr Beag Thrust (SBT). Location of Figure 2 indicated 814 in boxed area. Figure adapted from Goodenough et al. (2011). British National Grid 815 coordinates (NC) provided.

816 Figure 2. Geology of the Loch Loyal Syenite Complex based on King (1942), Robertson and 817 Parsons (1974), Holdsworth et al. (1999), Holdsworth et al. (2001), published BGS 1:50,000 818 geological maps of the area, and the new mapping presented here. Three individual 819 intrusions: Ben Loyal (BL), Beinn Stumanadh (BS), and Cnoc nan Cuilean (CnC). Faults 820 including the Loch Loyal Fault and two faults (F1 and F2) within the Cnoc nan Cuilean 821 intrusion. Surrounding country rock foliations delineated from field measurements and 822 adapted from Holdsworth et al. 1999. Location of Figure 3 indicated by boxed area. British 823 National Grid coordinates (NC) provided.

824 Figure 3. Detailed geology of the Cnoc nan Cuilean intrusion. Inset boxes indicate positions 825 of close-up maps (Fig. 5) around the intrusion margins. Vein size has been over-emphasised 826 for clarity in figure. Fault 1 (F1) and Fault 2 (F2) displayed. British National Grid coordinates 827 (NC) provided.

828 Figure 4. (Colour online) Field and hand sample photographs of mixing/mingling textures 829 observed throughout the Cnoc nan Cuilean intrusion. (a) Lobate contact of dark-coloured 830 melasyenites with lighter leucosyenites (contact highlighted by white lines). (b) Examples of 831 melasyenite-leucosyenite complex mixing and mingling textures (solid lines indicate 
832 mingling between melasyenite and leucosyenite, while dashed circles highlight gradational 833 relationships between these two lithologies, suggesting mixing). (c) Cut hand sample of 834 melasyenite and leucosyenite contact. Note the later leucosyenite vein (Lsy(2)) within Lsy(1) 835 earlier leucosyenite unit. (d) Pegmatite within leucosyenite (pegmatite contacts shown by 836 white lines, with pyroxene selvage at margin). (e) Hand sample of nodule from a biotite837 magnetite vein (Allt Liath) showing leucosyenite veining, coarse and vuggy magnetite and 838 dark-coloured mineral phases including clinopyroxene, biotite, and allanite. (f) Leucosyenite 839 with altered and metasomatised country rock (?Lewisianoid) xenolith displaying relict 840 foliation. Black lines highlight cross-cutting microgranite veinlets.

841 Figure 5. Close-up maps of the Cnoc nan Cuilean intrusion margins delineating country rock 842 foliation, structural measurements, and concordant and discordant veins. British National 843 Grid coordinates (NC) provided.

844 Figure 6. Cross-sections of the Cnoc nan Cuilean intrusion showing broad synform within the 845 country rocks, into which the lopolith form of the MZ sits, overprinted by later intrusive 846 events associated with the LZ. LLF is Loch Loyal Fault, F1 and F2 are Faults 1 and 2 847 respectively, within the Cnoc nan Cuilean intrusion.

848 Figure 7. (colour online) Snapshot views of the 3D GoCAD ${ }^{\mathrm{TM}}$ model of the Cnoc nan Cuilean 849 intrusion. (a) Plan view of the intrusion showing contoured topographic surface. (b) View 850 from beneath the NW corner of the intrusion. (c) View from $E$ of the intrusion, 851 demonstrating the lopolith shape of the $\mathrm{MZ}$ and more elongate vertical body of the $\mathrm{MZ}$ 852 (white line indicates ground level of the margin of the intrusion). (d) View from $\mathrm{N}$ of the 853 intrusion. MZ is the yellow body (or lighter grey in print), LZ is the red body (or darker grey 854 in print). 
855 Figure 8. (Colour online) Photomicrographs of textures for syenites. (a) Clustered

856 clinopyroxene, titanite, and apatite in melasyenite stringer. Fine dark brown allanite 857 interstitial within this stringer. Coarse perthitic K-feldspar either side of mafic mineral 858 stringer. (b) Example orbicular texture in melasyenite, with green clinopyroxene, amphibole, 859 and titanite forming rounded clusters between coarse K-feldspar crystals. Orbicule centres 860 also with coarse perthitic K-feldspar. (c) Coarse rounded apatite crystal (from melasyenite) 861 with a partial allanite rim and surrounded by K-feldspar (with albite exsolution) and 862 prismatic clinopyroxene. Apatite is inclusion-rich (often magnetite flecks) with allanite 863 infilling fractures.

864 Figure 9. Selection of Scanning Electron Microscope Back Scattered Electron images of 865 samples from the Cnoc nan Cuilean intrusion. (a) Interstitial allanite between euhedral and 866 subhedral clinopyroxene, titanite, and apatite (with K-feldspar and albite exsolution 867 lamellae in top of view) in melasyenite. (b) Allanite infilling fractures through coarse 868 clinopyroxene crystals within melasyenite sample. Bright thorite also seen as rounded 869 crystals infilling vugs or fractures. Mineral abbreviations: apatite (Ap), clinopyroxene (Cpx), 870 titanite (Ttn), allanite (Aln), and thorite (Thr).

871 Figure 10. Scanning Electron Microscope Back Scattered Electron image of biotite-magnetite 872 vein material showing (a) allanite with an allanite-like banded mineral and (b) baryte, 873 thorite, and apatite infilling a large vug within a fractured magnetite crystal. (c) 874 Photomicrograph of a metasomatised melasyenite sample exposed adjacent and external to 875 biotite-magnetite veins. Poikilitic amphibole has abundant inclusions of apatite, while small 876 tabular biotite and cryptocrystalline carbonate replace and overprint the original feldspar 877 component of the syenite. Mineral abbreviations: apatite (Ap), clinopyroxene (Cpx), 
878 amphibole (Am), biotite (Bt), titanite (Ttn), allanite (Aln), allanite-like mineral (Aln-like),

879 magnetite (Mag), thorite (Thr), baryte (Brt), REE-Sr carbonate veining mineral (REE-Sr carb), 880 and carbonate $\left(\mathrm{CO}_{3}\right)$.

881 Figure 11. Schematic diagram demonstrating the formation events of the Cnoc nan Cuilean 882 intrusion. 


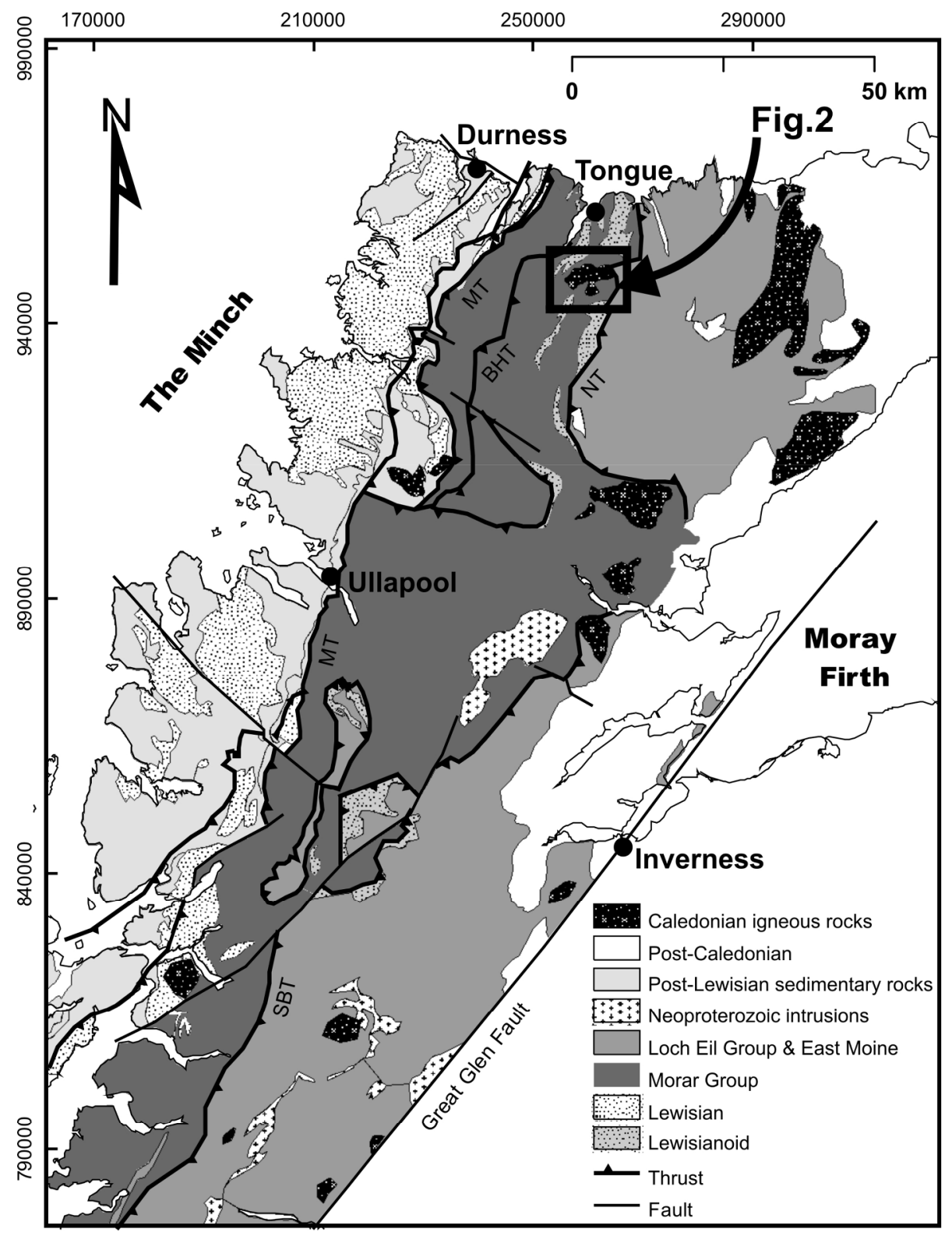

Figure 1. Simplified regional geological map of NW Scotland, displaying the main faults, thrust, and Caledonian intrusions. Major thrusts include: Moine Thrust (MT), Naver Thrust (NT), Ben Hope Thrust (BHT), and the Sgurr Beag Thrust (SBT). Location of Figure 2 indicated in boxed area. Figure adapted from Goodenough et al. (2011). British National Grid coordinates (NC) provided. $99 \times 131 \mathrm{~mm}(600 \times 600 \mathrm{DPI})$ 


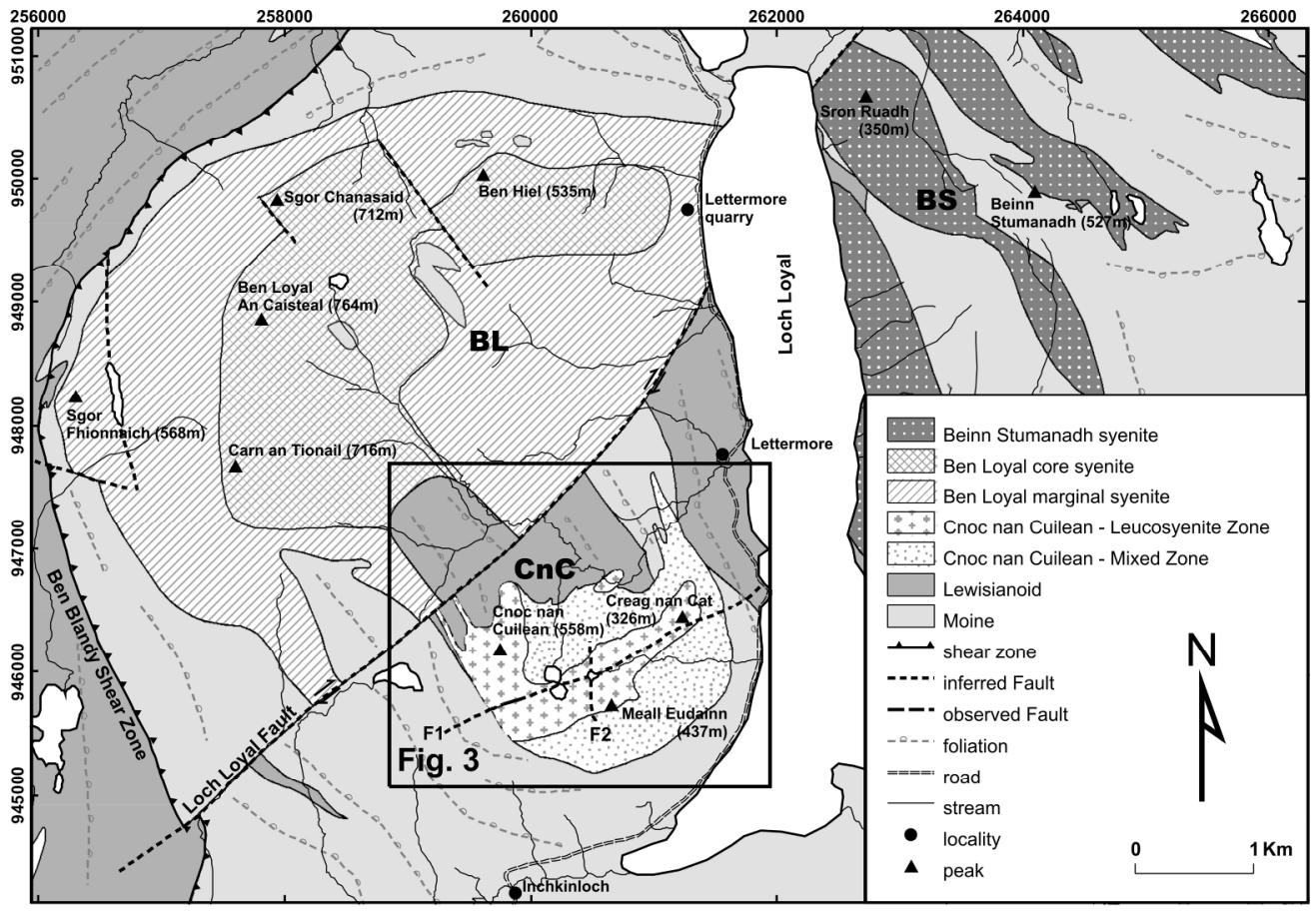

Figure 2. Geology of the Loch Loyal Syenite Complex based on King (1942), Robertson and Parsons (1974), Holdsworth et al. (1999), Holdsworth et al. (2001), published BGS 1:50,000 geological maps of the area, and the new mapping presented here. Three individual intrusions: Ben Loyal (BL), Beinn Stumanadh (BS), and $\mathrm{Cnoc}$ nan Cuilean ( $\mathrm{CnC}$ ). Faults including the Loch Loyal Fault and two faults (F1 and F2) within the Cnoc nan Cuilean intrusion. Surrounding country rock foliations delineated from field measurements and adapted from Holdsworth et al. 1999. Location of Figure 3 indicated by boxed area. British National Grid coordinates (NC) provided. $114 \times 78 \mathrm{~mm}(600 \times 600 \mathrm{DPI})$ 
Figure 3. Detailed geology of the Cnoc nan Cuilean intrusion. Inset boxes indicate positions of close-up maps (Fig. 5) around the intrusion margins. Vein size has been over-emphasised for clarity in figure. Fault 1 (F1) and Fault 2 (F2) displayed. British National Grid coordinates (NC) provided. $117 \times 81 \mathrm{~mm}(600 \times 600 \mathrm{DPI})$ 

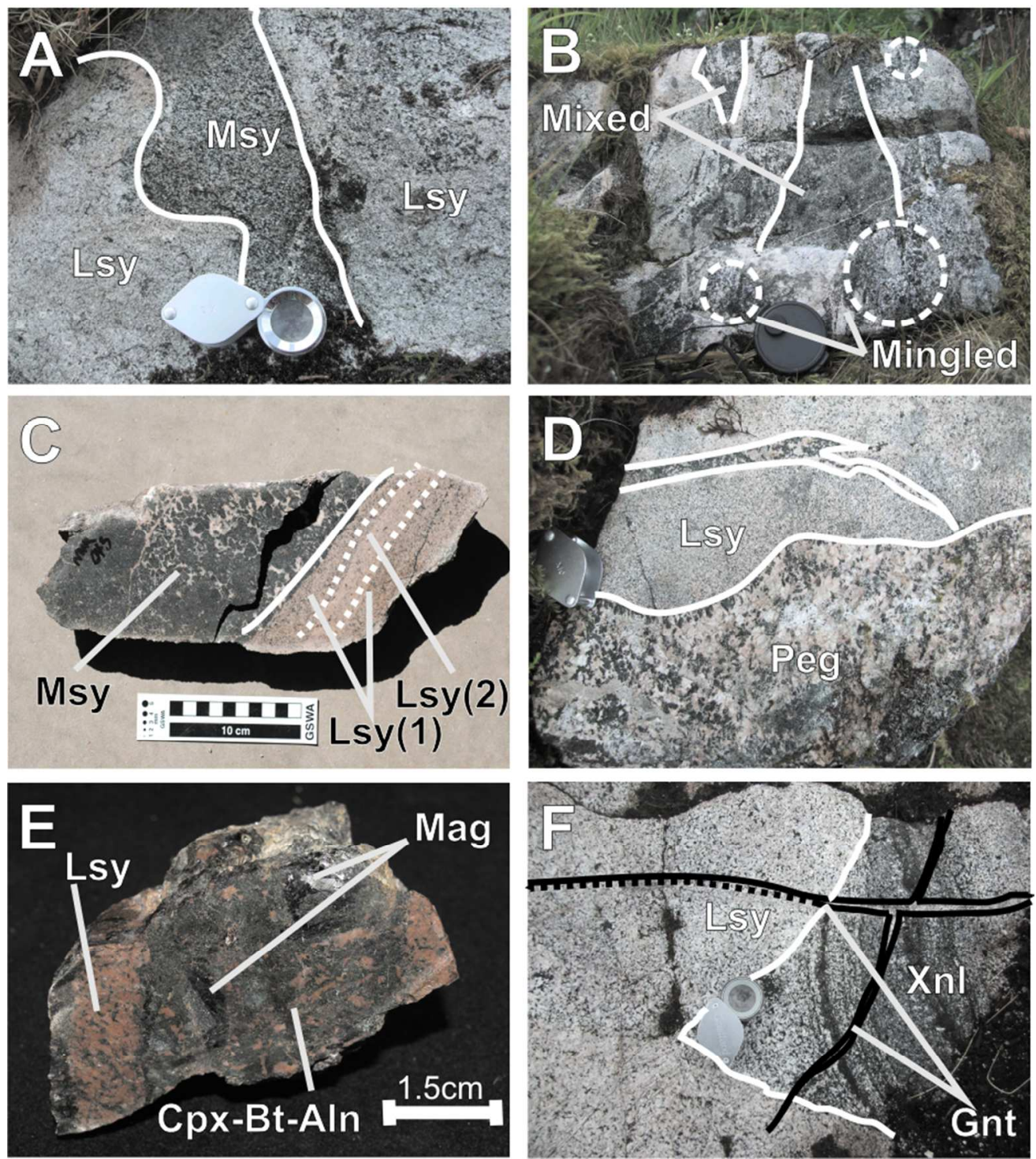

Figure 4. (Colour online) Field and hand sample photographs of mixing/mingling textures observed throughout the Cnoc nan Cuilean intrusion. (a) Lobate contact of dark-coloured melasyenites with lighter leucosyenites (contact highlighted by white lines). (b) Examples of melasyenite-leucosyenite complex mixing and mingling textures (solid lines indicate mingling between melasyenite and leucosyenite, while dashed circles highlight gradational relationships between these two lithologies, suggesting mixing). (c) Cut hand sample of melasyenite and leucosyenite contact. Note the later leucosyenite vein (Lsy(2)) within Lsy(1) earlier leucosyenite unit. (d) Pegmatite within leucosyenite (pegmatite contacts shown by white lines, with pyroxene selvage at margin). (e) Hand sample of nodule from a biotite-magnetite vein (Allt Liath) showing

leucosyenite veining, coarse and vuggy magnetite and dark-coloured mineral phases including

clinopyroxene, biotite, and allanite. (f) Leucosyenite with altered and metasomatised country rock (?Lewisianoid) xenolith displaying relict foliation. Black lines highlight cross-cutting microgranite veinlets. $78 \times 88 \mathrm{~mm}(300 \times 300 \mathrm{DPI})$ 


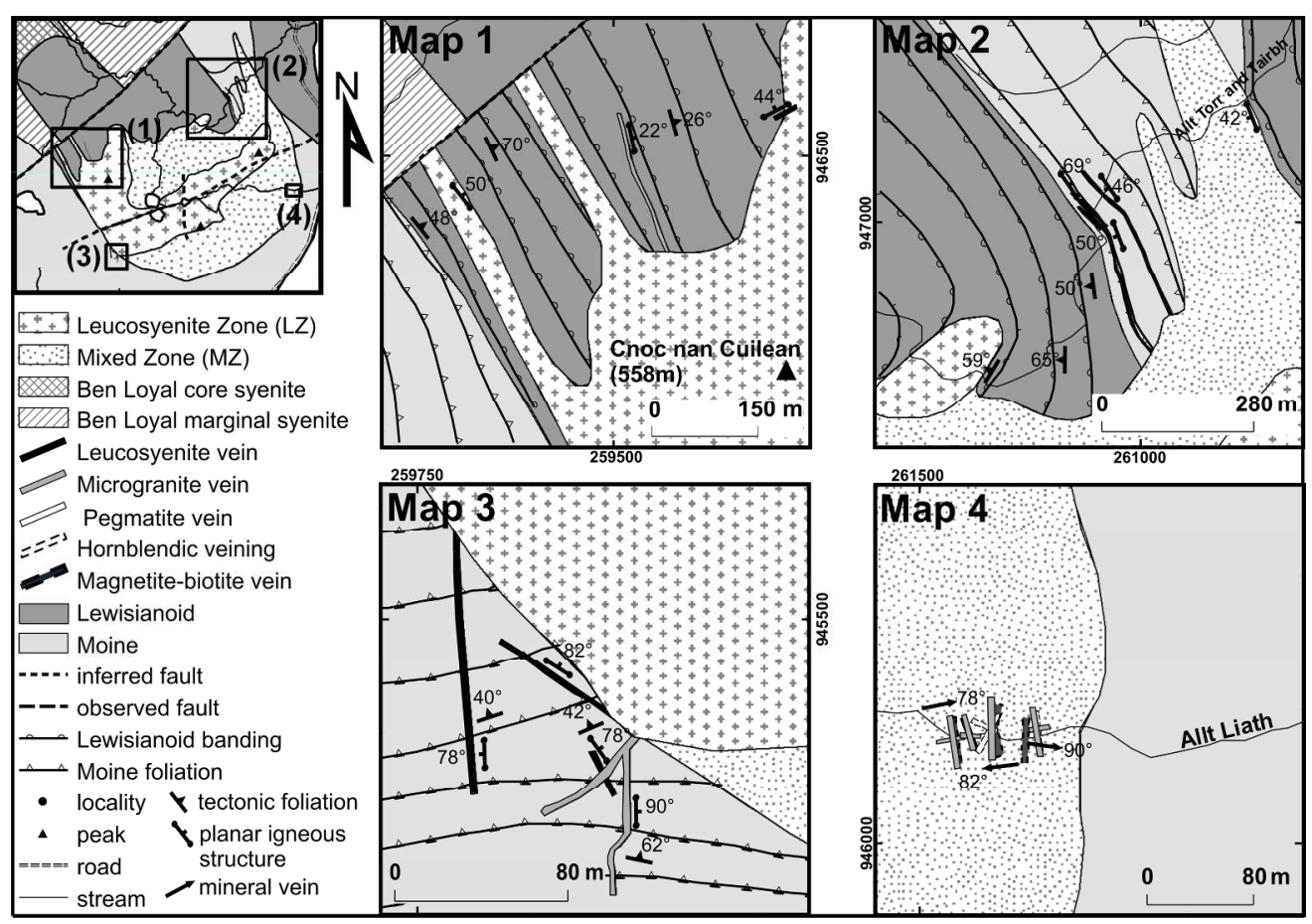

Figure 5. Close-up maps of the Cnoc nan Cuilean intrusion margins delineating country rock foliation, structural measurements, and concordant and discordant veins. British National Grid coordinates (NC) provided.

$116 \times 80 \mathrm{~mm}(600 \times 600 \mathrm{DPI})$ 
Figure 6. Cross-sections of the Cnoc nan Cuilean intrusion showing broad synform within the country rocks, into which the lopolith form of the MZ sits, overprinted by later intrusive events associated with the LZ. LLF is Loch Loyal Fault, F1 and F2 are Faults 1 and 2 respectively, within the Cnoc nan Cuilean intrusion. $165 \times 118 \mathrm{~mm}(600 \times 600 \mathrm{DPI})$

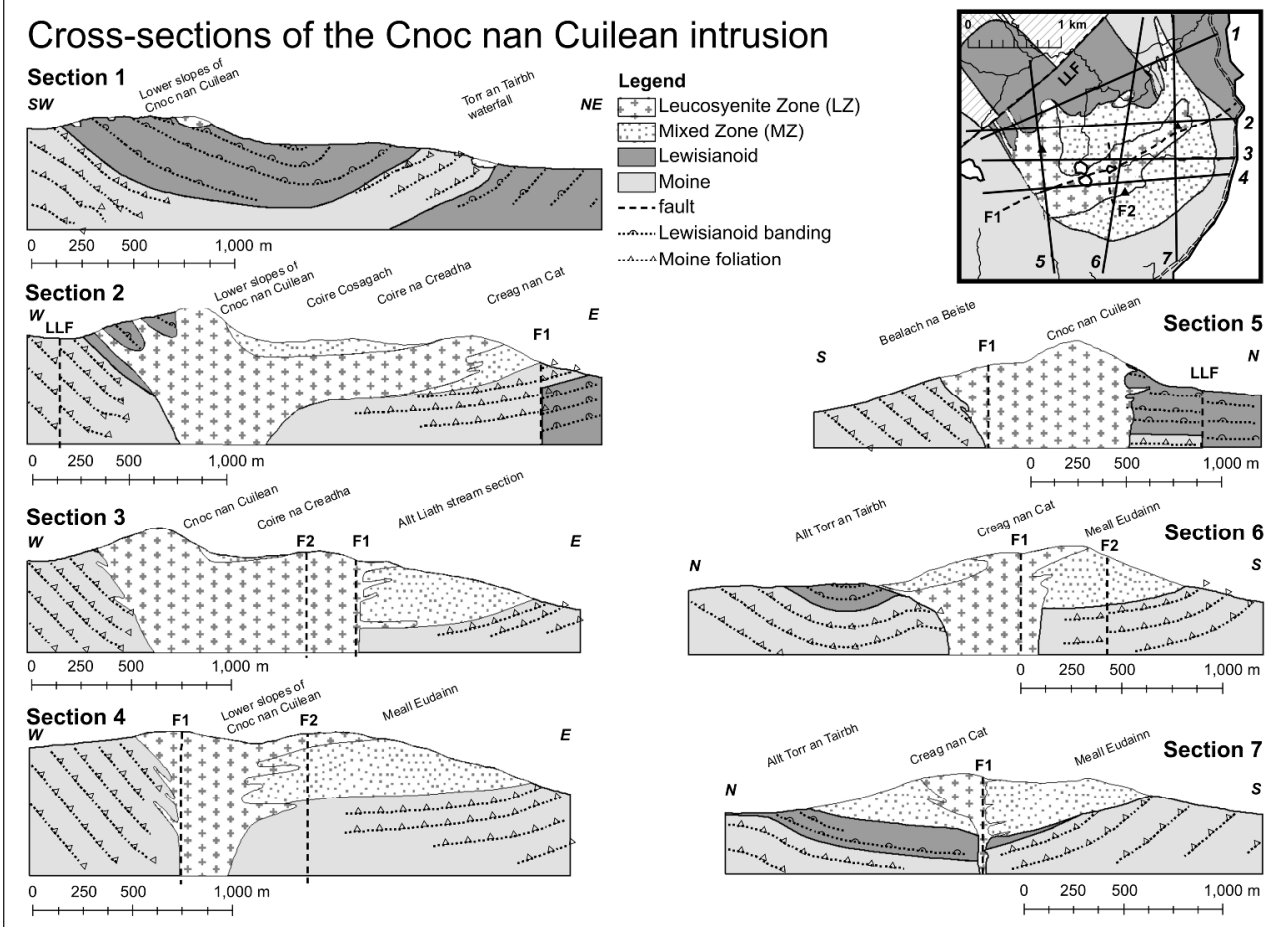


Figure 7. (Colour online) Snapshot views of the 3D GoCADTM model of the Cnoc nan Cuilean intrusion. (a) Plan view of the intrusion showing contoured topographic surface. (b) View from beneath the NW corner of the intrusion. (c) View from $\mathrm{E}$ of the intrusion, demonstrating the lopolith shape of the $\mathrm{MZ}$ and more elongate vertical body of the $M Z$ (white line indicates ground level of the margin of the intrusion). (d) View from $\mathrm{N}$ of the intrusion. $\mathrm{MZ}$ is the yellow body (or lighter grey in print), LZ is the red body (or darker grey in print).

$123 \times 98 \mathrm{~mm}(300 \times 300 \mathrm{DPI})$ 
Figure 8. (Colour online) Photomicrographs of textures for syenites. (a) Clustered clinopyroxene, titanite, and apatite in melasyenite stringer. Fine dark brown allanite interstitial within this stringer. Coarse perthitic K-feldspar either side of mafic mineral stringer. (b) Example orbicular texture in melasyenite, with green clinopyroxene, amphibole, and titanite forming rounded clusters between coarse K-feldspar crystals. Orbicule centres also with coarse perthitic K-feldspar. (c) Coarse rounded apatite crystal (from melasyenite) with a partial allanite rim and surrounded by K-feldspar (with albite exsolution) and prismatic clinopyroxene. Apatite is inclusion-rich (often magnetite flecks) with allanite infilling fractures. $174 \times 400 \mathrm{~mm}(300 \times 300$ DPI) 

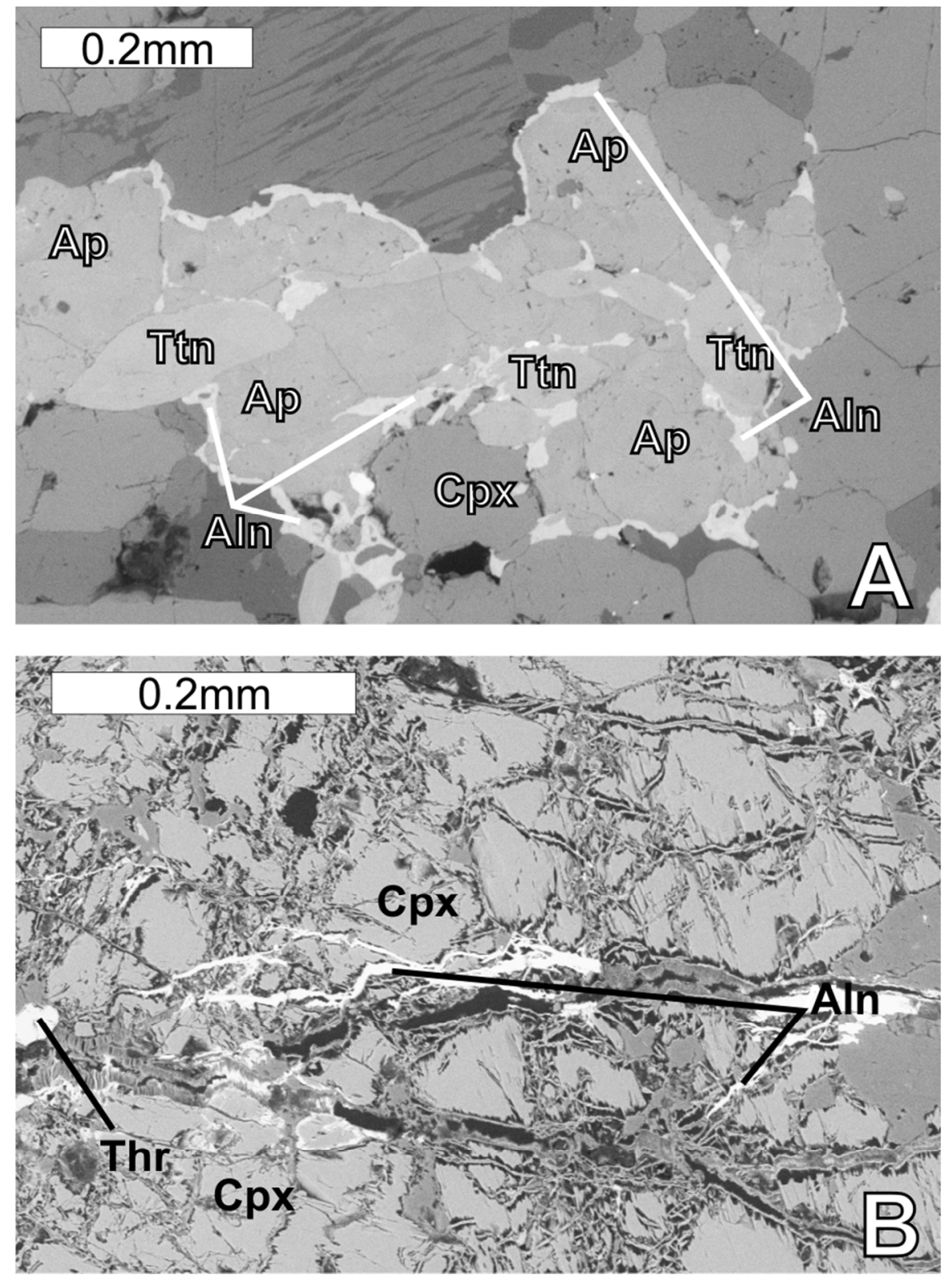

Figure 9. Selection of Scanning Electron Microscope Back Scattered Electron images of samples from the Cnoc nan Cuilean intrusion. (a) Interstitial allanite between euhedral and subhedral clinopyroxene, titanite, and apatite (with K-feldspar and albite exsolution lamellae in top of view) in melasyenite. (b) Allanite infilling fractures through coarse clinopyroxene crystals within melasyenite sample. Bright thorite also seen as rounded crystals infilling vugs or fractures. Mineral abbreviations: apatite (Ap), clinopyroxene (Cpx), titanite (Ttn), allanite (Aln), and thorite (Thr). $75 \times 103 \mathrm{~mm}(300 \times 300 \mathrm{DPI})$ 
Figure 10. Scanning Electron Microscope Back Scattered Electron image of biotite-magnetite vein material showing (a) allanite with an allanite-like banded mineral and (b) baryte, thorite, and apatite infilling a large vug within a fractured magnetite crystal. (c) Photomicrograph of a metasomatised melasyenite sample exposed adjacent and external to biotite-magnetite veins. Poikilitic amphibole has abundant inclusions of apatite, while small tabular biotite and cryptocrystalline carbonate replace and overprint the original feldspar component of the syenite. Mineral abbreviations: apatite (Ap), clinopyroxene (Cpx), amphibole (Am), biotite

$(\mathrm{Bt})$, titanite (Ttn), allanite (Aln), allanite-like mineral (Aln-like), magnetite (Mag), thorite (Thr), baryte (Brt), REE-Sr carbonate veining mineral (REE-Sr carb), and carbonate (CO3). $75 \times 170 \mathrm{~mm}(300 \times 300$ DPI $)$ 

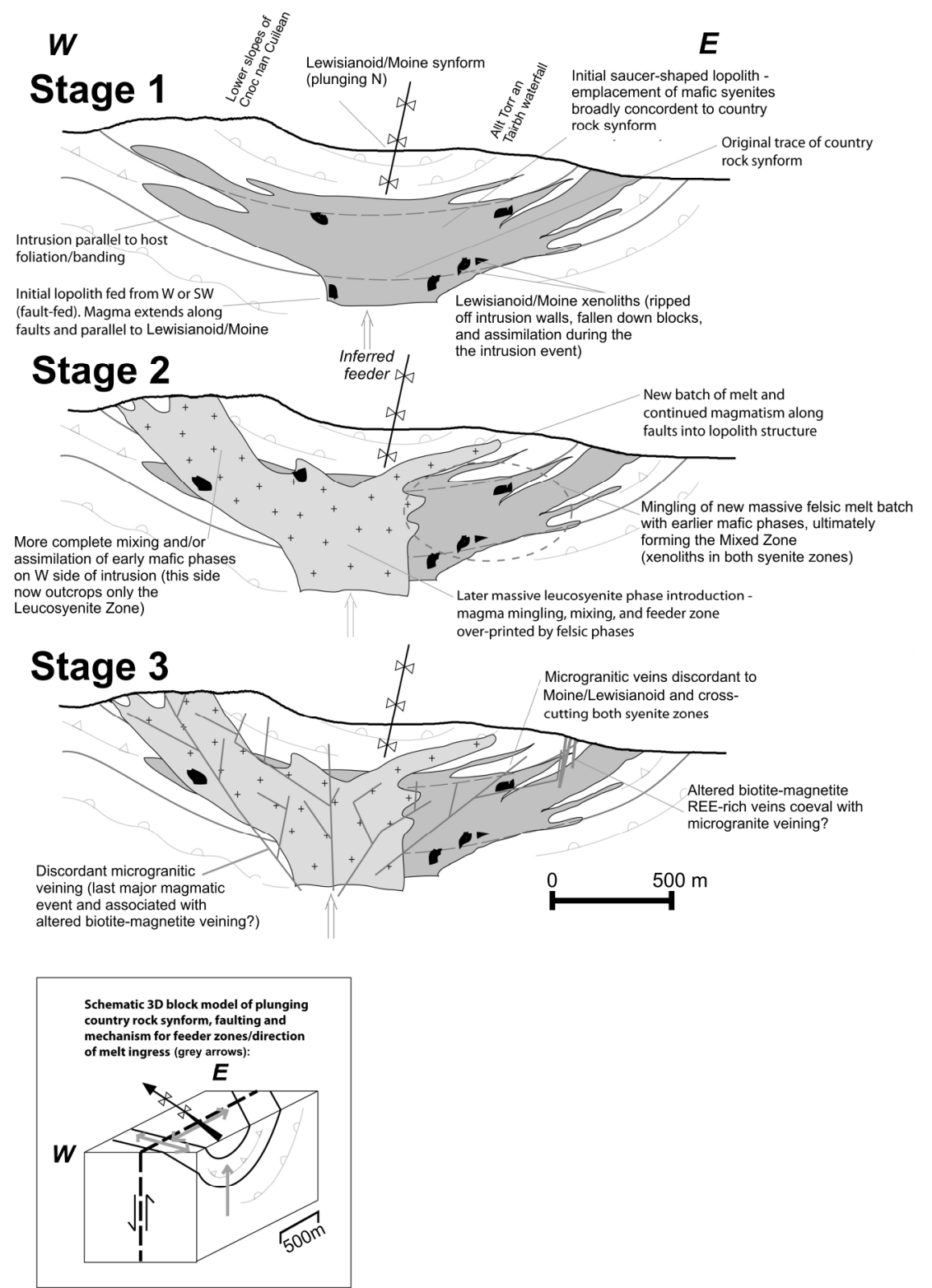

Figure 11. Schematic diagram demonstrating the formation events of the Cnoc nan Cuilean intrusion. $170 \times 227 \mathrm{~mm}(300 \times 300 \mathrm{DPI})$ 